\title{
EQUILIBRIUM AND ANTIBACTERIAL STUDIES OF VO(II) AND Zn(II) COMPLEXES WITH 1-PROPIONYL-3- THIOSEMICARBAZIDE
}

\author{
P. Nirmala Jyothi and B. Sireesha* \\ ${ }^{a}$ Department of Chemistry, Nizam College, Osmania University, Hyderabad-500001, (TS) India. \\ *E-mail: berleysiree@gmail.com
}

\begin{abstract}
Vanadyl(II) and Zinc(II) metal complexes with Schiff base 1-propionyl-3-thiosemicarbazide were synthesized and characterized by LCMS, IR, ${ }^{1} \mathrm{H}-\mathrm{NMR}\left(\mathrm{D}_{2} \mathrm{O}\right.$ exchangeable), ${ }^{13} \mathrm{C}-\mathrm{NMR}$, UV-Visible spectra, ESR, TGA, molar conductance and magnetic susceptibility measurements. The spectro-analytical studies revealed the composition as ML for Vanadyl(II) complex and $\mathrm{ML}_{2}$ for Zinc(II) complex. Equilibrium studies revealed that 1-propionyl-3thiosemicarbazide acts as a monobasic ligand by releasing proton from amide and forms 1:1 and 1:2 complex in solution. The cleavage of plasmid pBR322 DNA exhibited hydrolytic cleavage. The compound and its chelates showed antibacterial activity against gram-positive and gram-negative bacteria.
\end{abstract}

Keywords: Equilibrium Studies, LC-MS, UV, ESR, TGA, DNA Cleavage Studies

@ RASĀYAN. All rights reserved

\section{INTRODUCTION}

For decades novel drugs of an interesting structure, unknown molecular target, low toxicity and a high therapeutic index have been looked for. This has been due to the difficulty of treating many diseases, such as carcinoma or bacterial infections. The attention has been focused on thiosemicarbazide derivatives, which were investigated as a pharmacophore for antimicrobial and anticancer activity ${ }^{1}$. In vitro screening of thiosemicarbazide derivatives indicated microbial activities ${ }^{2-5}$. Numerous compounds showed good antibacterial activity against bacteria compared to the standard drug-ciprofloxacin and some of them were used in cancer treatment ${ }^{7-9}$. The derivatives have been excellently used against carcinoma cell lines ${ }^{10-13}$. The thiosemicarbazide derivatives exhibit cytotoxic and antiproliferative activity against HeLa (human epitheloid cervix carcinoma), HepG2 (human hepatocellular carcinoma), MDA-MB-231 (human breast adenocarcinoma), and HT-29 (human colorectal adenocarcinoma) cell lines ${ }^{14}$. The remarkable importance of the compounds has been observed in co-occurring of bacterial infections with dental caries causes chronic diseases such as endocarditis, myocardial infarction ${ }^{15-16}$, pancreatic and gastrointestinal cancer ${ }^{17}$. In vitro tests were performed against S. mutans and S. sanguinis to show the potency of thiosemicarbazide derivatives against oral bacteria ${ }^{18}$.

Potentiometry has been one of the most versatile techniques for determining stability constants. The $\mathrm{pH}$ of a solution is directly affected by chelate formation since chelation accompanies displacement of one or more protons from the chelating agent. In solution, complexes result from the reversible association of one or more metal ions with the ligand molecules and the complex formation is governed by the laws of chemical equilibrium and the greater the association more stable is the complex.

Transition metal complexes which cleave Deoxyribonucleic acid (DNA), under physiological conditions have been current interest in the development of artificial chemical nucleases. Of numerous applications of DNA cleavage studies the important ones being designing new drugs, DNA foot printing agents, in genomic research and in photodynamic therapy of cancers ${ }^{19-21}$. The present work explains the synthesis, characterization of $\mathrm{VO}$ (II) and $\mathrm{Zn}$ (II) complexes of 1-propionyl-3-thiosemicarbazide (PTSC), their DNA cleavage studies, antibacterial studies and Equilibrium studies of the title compound.

Rasayan J. Chem., 12(3), 1530-1539(2019)

http://dx.doi.org/10.31788/RJC.2019.1235182

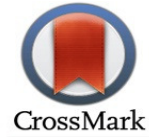


RASĀYAN J. Chem.

Vol. 12 | No. 3 |1530 - 1539| July - September | 2019

\section{Materials and Methods}

\section{EXPERIMENTAL}

The chemicals and solvents used were of AnalaR grade and used without further purification. Metal salts [ $\mathrm{VOSO}_{4}$ and $\left.\mathrm{ZnCl}_{2}\right]$ were used for the synthesis of complexes.

The conductance of the metal complexes solutions was determined in DMSO $\left(1 \times 10^{-3} \mathrm{M}\right)$ using Digisun digital conductivity meter model D1 909. LCMS of all the compounds were recorded on LCMS 2010 A, Shimadzu spectrophotometer. IR spectra were recorded in $\mathrm{KBr}$ phase $\left(4000 \mathrm{~cm}^{-1}\right.$ to $\left.250 \mathrm{~cm}^{-1}\right)$ on Shimadzu IR Prestige-21 FTIR spectrophotometer. ${ }^{1} \mathrm{H}$-NMR, ${ }^{13} \mathrm{C}-\mathrm{NMR}$ and $\mathrm{D}_{2} \mathrm{O}$ exchangeable ${ }^{1} \mathrm{H}-\mathrm{NMR}$ spectra have been taken on Bruker $400 \mathrm{mHz}$ NMR spectrophotometer. UV spectra were obtained from Shimadzu UV2450 spectrophotometer within the range of 200nm-1000nm. ESR spectra of complexes were obtained from EMX-PLUS-BRUKER X-band RT spectrometer. Magnetic susceptibilities of chelates were measured at room temperature on Faraday balance model 7550. Thermogravimetric analyses of the complexes were recorded on TA model DTG $60 \mathrm{H}$ SHIMADZU in the temperature range of $0^{\circ} \mathrm{C}-1100^{\circ} \mathrm{C}$ with a ramp of $20^{\circ} \mathrm{C} / \mathrm{min}$. Equilibrium studies were carried out on digital Elico (L1-120) $\mathrm{pH}$ meter with a combined glass and calomel electrode. DNA cleavage experiments were performed on Biotech electrophoresis system, supported by Genei power supply over a potential range of 50-500V. Further visualized and photographed by Biotech Trans-illuminator system. The antibacterial activity of the title compound and its chelates were tested using Kirby Bauer disc diffusion method.

\section{Synthesis of 1-propionyl-3-thiosemicarbazide (PTSC)}

1-propionyl-3-thiosemicarbazide was synthesized by refluxing equimolar solutions of thiosemicarbazide $(1.82 \mathrm{gm}, 20 \mathrm{mmol})$, propionic acid $(1.49 \mathrm{ml}, 20 \mathrm{mmol})$ and propionic anhydride $(2.5 \mathrm{ml}, 20 \mathrm{mmol})$ on a water bath for 30min. The progress of the reaction was monitored by TLC. The hot mixture was filtered and white square-shaped crystals of PTSC separated on slow cooling. The compound was soluble in methanol, ethanol, acetone and DMF. It was recrystallized from 2:1 methanol and benzene mixture (M.P: $\left.150-152^{\circ} \mathrm{C}\right)^{22}$.

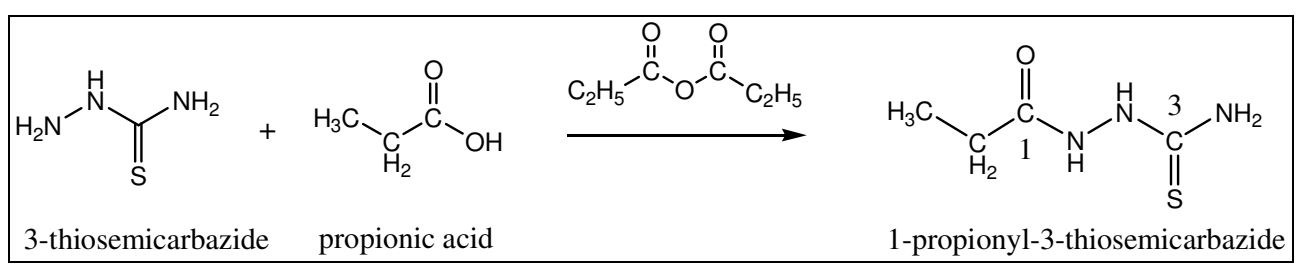

Scheme-1: Synthesis of 1-Propionyl-3-Thiosemicarbazide (PTSC)

\section{Synthesis of Metal Complexes}

Aqueous metal salt solution (VO(II)-0.3g, $1.7 \mathrm{mmol} / \mathrm{Zn}(\mathrm{II})-0.23 \mathrm{~g}, 1.7 \mathrm{mmol}$ ) was added to a hot methanolic solution of PTSC $(0.5 \mathrm{~g}, 3.4 \mathrm{mmol})$ in 1:2 molar ratio. The mixture was refluxed for about 5$10 \mathrm{hrs}$. The $\mathrm{pH}$ of the solution has been adjusted by the addition of methanolic ammonium hydroxide drop wise. The brown-colored VO(II)-PTSC complex and whitish colored Zn(II)-PTSC complex have been separated. These were filtered in hot condition, washed with hot methanol to remove unreacted ligand and with double distilled water to remove metal salts. Finally washed with petroleum ether and dried in vacuum.

\section{Equilibrium Studies}

To understand the chelating properties of PTSC in solution an attempt is made to know the potential binding sites that coordinate with metal ions. Irving-Rossetti potentiometric $\mathrm{pH}$ titration technique in $70 \% \mathrm{v} / \mathrm{v}$ DMF-water medium at $303 \mathrm{~K}$ and $0.1 \mathrm{M} \mathrm{KNO}_{3}$ ionic strength was employed for the determination of dissociation constant of PTSC and the stability constants of PTSC with Zn(II) ions ${ }^{23-30}$.

\section{DNA Cleavage Studies}

pBR322 plasmid DNA was dissolved in a buffer containing 10mM Tris- $\mathrm{HCl}(\mathrm{pH} 7.5), 1 \mathrm{mM}$ EDTA and $0.1 \%$ sodium azide. Tris Acetate EDTA buffer ( $\mathrm{pH} 8.0$ ) was prepared using $40 \mathrm{mM}$ Tris base, $20 \mathrm{mM}$ 
acetic acid and $1 \mathrm{mM} \mathrm{Na} 2$ EDTA, and used for gel electrophoresis. The complexes $(15-45 \mu \mathrm{M})$ were treated with $3 \mu \mathrm{L}$ of super coiled pBR322 DNA $(100 \mathrm{ng} / \mu \mathrm{L})$, incubated for an hour at $37^{\circ} \mathrm{C}$. Then $1 \mu \mathrm{L}$ loading buffer $(0.25 \%$ bromophenol blue) was added and loaded onto a $0.8 \%$ agarose gel. This was subjected to electrophoresis at $60 \mathrm{~V}$ for two hours making sure that bromophenol blue had traveled through $75 \%$ of the gel. The gel was then stained with Ethidium bromide and destained in sterile distilled water. The trans-illuminator was used to visualize the plasmid bands and photographed.

\section{Biological Activity}

Kirby-Bauer disc diffusion method was used to monitor the biological activity of PTSC and its complexes, in $0.10 \mathrm{ml}$ of test bacteria. Staphylococcus aureus, Bacillus Subtilis (gram-positive) and Klebsiella pneumonia, Escherchia coli (gram-negative) have been used for the study. Bacterial solutions were spread evenly on the surface of nutrient agar. $5 \mathrm{~mm}$ diameter sterile discs with $5 \mathrm{ml}$ capacity dipped in sample solutions were placed on the surface equidistance. The samples tested had the potency of $1250 \mu \mathrm{g} /$ disc. DMSO was taken as control which does not exhibit any inhibitory activity. Gentamycin was used as standard. All the Petri-plates were incubated for $24 \mathrm{hrs}$ at $37^{\circ} \mathrm{C}$. The average of the tests run in triplicates have been reported.

\section{Characterization of PTSC}

\section{RESULTS AND DISCUSSION}

PTSC: White shiny crystals; yield: $85 \%$; m.p: $150-152^{\circ} \mathrm{C}$; elemental analyses: calculated (\%) for $\mathrm{C}_{4} \mathrm{H}_{9} \mathrm{~N}_{3} \mathrm{OS}$ : C, 32.65, H, 6.12, N, 28.57. found (\%): C, 32.62, H, $6.10 \mathrm{~N}, 28.55$. UV-visible in DMSO, $\lambda_{\max } / \mathrm{nm}$ : 240.9 and 207; IR $\left(\mathrm{KBr} / \mathrm{cm}^{-1}\right): 3407 \mathrm{~cm}^{-1} v_{\mathrm{as}}(\mathrm{NH} 2), 3284 \mathrm{~cm}^{-1} v_{\mathrm{s}}\left(\mathrm{NH}_{2}\right), 3193 \mathrm{~cm}^{-1} \quad\left(v_{\mathrm{N}-\mathrm{H}}\right.$ amide $)$, $3140 \mathrm{~cm}^{-1}\left(v_{\mathrm{N}-\mathrm{H}}\right.$ thioamide $), 2987 \mathrm{~cm}^{-1}\left(v_{\mathrm{CH} 2}\right), 2948 \mathrm{~cm}^{-1}\left(v_{\mathrm{CH} 3}\right), 1683 \mathrm{~cm}^{-1}\left(v_{\mathrm{C}=\mathrm{O}}\right), 1269 \mathrm{~cm}^{-1}\left(v_{\mathrm{C}=\mathrm{S}}\right)$ and $932 \mathrm{~cm}^{-1}\left(v_{\mathrm{N}-\mathrm{N}}\right)^{31,}{ }^{32} .{ }^{1} \mathrm{H}-\mathrm{NMR}(400 \mathrm{MHz}, \mathrm{DMSO}-\mathrm{d} 6, \delta / \mathrm{ppm}): \delta 9.8(\mathrm{~s}, 1 \mathrm{H}, \mathrm{OH}), \delta 9.5(\mathrm{~s}, 1 \mathrm{H}, \mathrm{NH}), \delta 9.0(\mathrm{~s}$, $1 \mathrm{H}, \mathrm{NH}), \delta 7.6(\mathrm{~s}, 1 \mathrm{H}, \mathrm{SH}), \delta 7.2\left(\mathrm{~m}, 2 \mathrm{H}, \mathrm{NH}_{2}\right), \delta 3.5 \quad\left(\mathrm{~s}, 2 \mathrm{H}, \mathrm{CH}_{2}\right)$ and $\delta 2.5\left(\mathrm{~s}, 3 \mathrm{H}, \mathrm{CH}_{3}\right) .{ }^{13} \mathrm{C}-\mathrm{NMR}$ (DMSO-d6, $\delta / \mathrm{ppm}): \delta 10\left(\mathrm{CH}_{3}\right), \delta 28\left(\mathrm{CH}_{2}\right), \delta 172, \delta 175(\mathrm{C}=\mathrm{O})$ and $\delta 180(\mathrm{C}=\mathrm{S}), \mathrm{MS}(+): \mathrm{m} / \mathrm{z} 148.15$ $[\mathrm{M}+1]^{+}, 171.15[\mathrm{M}+\mathrm{Na}]^{+}$.

\section{Equilibrium Studies}

The titration data were used to calculate (Table-1), the dissociation constant by plotting linear graphs of $\log \left(1-\bar{n}_{\mathrm{A}}\right) /\left(\bar{n}_{\mathrm{A}}\right) \mathrm{Vs} \mathrm{pH}$ (Fig.-1). It predicted the presence of one dissociable proton corresponding to amide $(-\mathrm{NH})$ proton via enol formation $(\mathrm{pKa}=9.55)$. ${ }^{1} \mathrm{H}-\mathrm{NMR}$ and ${ }^{13} \mathrm{C}-\mathrm{NMR}$ studies also indicate ketoenol tautomerism in PTSC. Values of $\bar{n}$ ranges from 0.2 to $1.9\left(\operatorname{Logk}_{1}=9.02, \operatorname{Logk}_{2}=8.3\right.$ in DMF medium) (Table-2), indicating formation of 1:1 and 1:2 complex in solution. The stability constant of the binary complex was obtained from linear plots of $\log [(1-\bar{n}) / \bar{n}] \mathrm{Vs} \mathrm{pL}$ and $\log (2-\bar{n}) /(\bar{n}-1)$ Vs pL (Fig.- 2, 3). These values are further refined by using MINIQUAD program ${ }^{31}$.

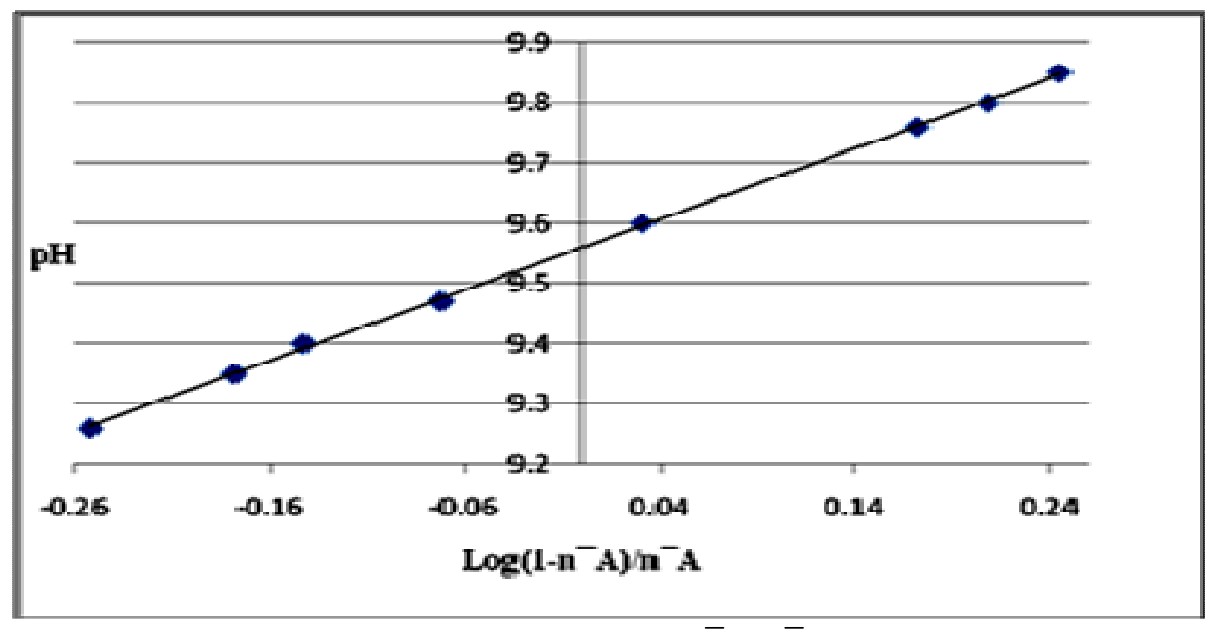

Fig.-1: Linear Plot of Log $\left[\left(1-\bar{n}_{\mathrm{A}}\right) / \bar{n}_{\mathrm{A}}\right]$ Vs pH

1532 
Table-1: Data for obtaining Dissociation Constants of PTSC

\begin{tabular}{c|c|c}
\hline $\mathrm{pH}$ & $\bar{n}_{\mathrm{A}}$ & $\log \left(1-\bar{n}_{\mathrm{A}}\right) /\left(\bar{n}_{\mathrm{A}}\right)$ \\
\hline 9.2 & 0.641 & -0.2517 \\
\hline 9.3 & 0.6011 & -0.178 \\
\hline 9.4 & 0.5813 & -0.1424 \\
\hline 9.5 & 0.5414 & -0.072 \\
\hline 9.6 & 0.4817 & 0.0318 \\
\hline 9.7 & 0.402 & 0.1724 \\
\hline 9.8 & 0.3822 & 0.2085 \\
\hline 9.9 & 0.3623 & 0.2455 \\
\hline
\end{tabular}

Table-2: Data for obtaining Formation Curves of Zn(II)-PTSC at 303K and 0.1M Ionic strength in $70 \%$ v/v DMF-Water Medium.

\begin{tabular}{c|c|c|c|c|c|}
\hline \multicolumn{7}{|c|}{$\mathrm{Zn}(\mathrm{II})-\mathrm{PTSC}(\mathrm{DMF}$ Medium) } \\
\hline $\bar{n}$ & $\log (1-\bar{n}) / \bar{n}$ & $\mathrm{pL}$ & $\bar{n}$ & $\log (2-\bar{n}) /(\bar{n}-1)$ & $\mathrm{pL}$ \\
\hline 0.2 & 0.6020 & 9.38 & & & \\
\hline 0.3 & 0.3679 & 9.25 & 1.3 & 0.3679 & 8.54 \\
\hline 0.4 & 0.1760 & 9.14 & 1.4 & 0.1760 & 8.46 \\
\hline 0.5 & 0 & 9.02 & 1.5 & 0 & 8.39 \\
\hline 0.6 & -0.1760 & 8.91 & 1.6 & -0.1760 & 8.3 \\
\hline 0.7 & -0.3679 & 8.79 & 1.7 & -0.3679 & 8.23 \\
\hline 0.8 & -0.6020 & 8.66 & 1.8 & -0.6020 & 8.13 \\
\hline \multicolumn{7}{|l}{}
\end{tabular}

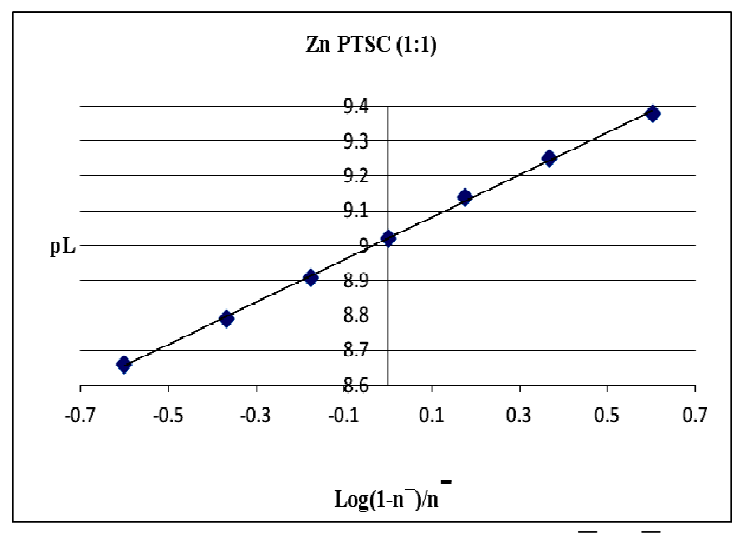

Fig.-2: Linear Plots of $\log [(1-\bar{n}) / \bar{n}] \mathrm{Vs} \mathrm{pL}$

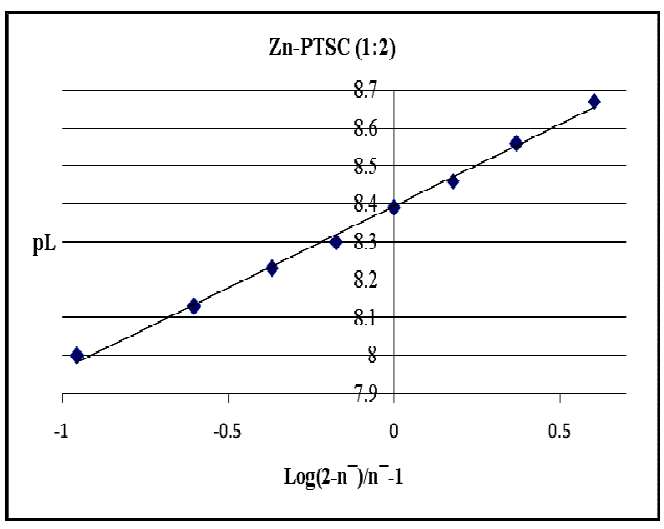

Fig.-3: $\log (2-\bar{n}) /(\bar{n}-1) \mathrm{Vs} \mathrm{pL}$

\section{Characterization of Metal Complexes of PTSC}

$\mathrm{VO}(\mathrm{II})$ and $\mathrm{Zn}$ (II) chelates of PTSC were amorphous, quite stable to air and moisture and were soluble in DMF and DMSO, decomposed above $300^{\circ} \mathrm{C}$. Molar conductivities recorded in DMSO were in the range of $7-9 \mathrm{ohm}^{-1} \mathrm{~cm}^{-1} \mathrm{~mol}^{-1}$ suggesting the non electrolytic nature of the complexes. Volhard's test gave negative results for the presence of chloride ion $^{33}$.

\section{Liquid Chromatograms}

VO(II)-PTSC (Fig.-4) and Zn(II)-PTSC (Fig.-5) complexes were pure and showed single peaks in their liquid chromatograms at retention times $0.713 \mathrm{~min}$ and $0.670 \mathrm{~min}$ respectively.

Mass: Mass spectrum of VO(II)-PTSC chelate (Fig.-6) showed a molecular ion peak at m/z 231 $\left[\mathrm{ML} . \mathrm{H}_{2} \mathrm{O}\right]^{+}$. The $\mathrm{m} / \mathrm{z}$ values of other peaks recorded were $213[\mathrm{ML}]$ and 51 corresponds to Vanadium ion. 
Mass spectrum of $\mathrm{Zn}$ (II)-PTSC (Fig.-7) revealed the molecular ion peak at m/z $411\left[\mathrm{ML}_{2} \cdot 2 \mathrm{H}_{2} \mathrm{O} \mathrm{H}_{2} \mathrm{O}^{+}\right.$. Other fragmentation peaks at m/z $393\left[\mathrm{ML}_{2} \cdot 2 \mathrm{H}_{2} \mathrm{O}\right]^{+}, \mathrm{m} / \mathrm{z} 375\left[\mathrm{ML}_{2} \cdot \mathrm{H}_{2} \mathrm{O}\right]^{+}, \mathrm{m} / \mathrm{z} 357\left[\mathrm{ML}_{2}\right]^{+}, \mathrm{m} / \mathrm{z} 212$ $[\mathrm{ML}+1]^{+}$and $\mathrm{m} / \mathrm{z} 65$ corresponding to Zinc ion were observed.

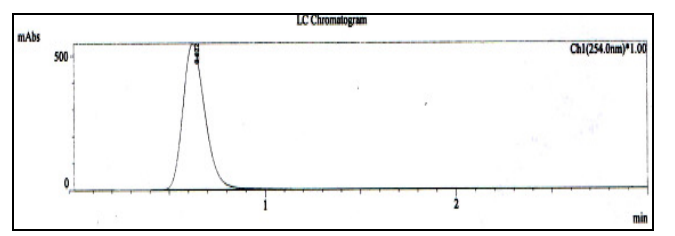

Fig.-4: Liquid Chromatogram of VO(II)-PTSC

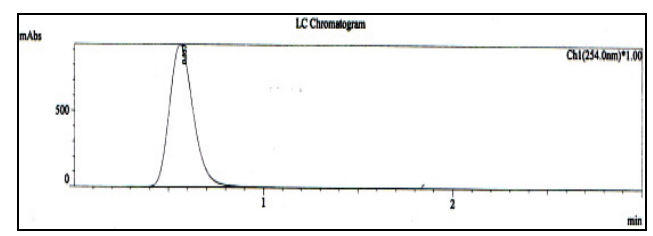

Fig.-5:Liquid Chromatogram of Zn(II)-PTSC
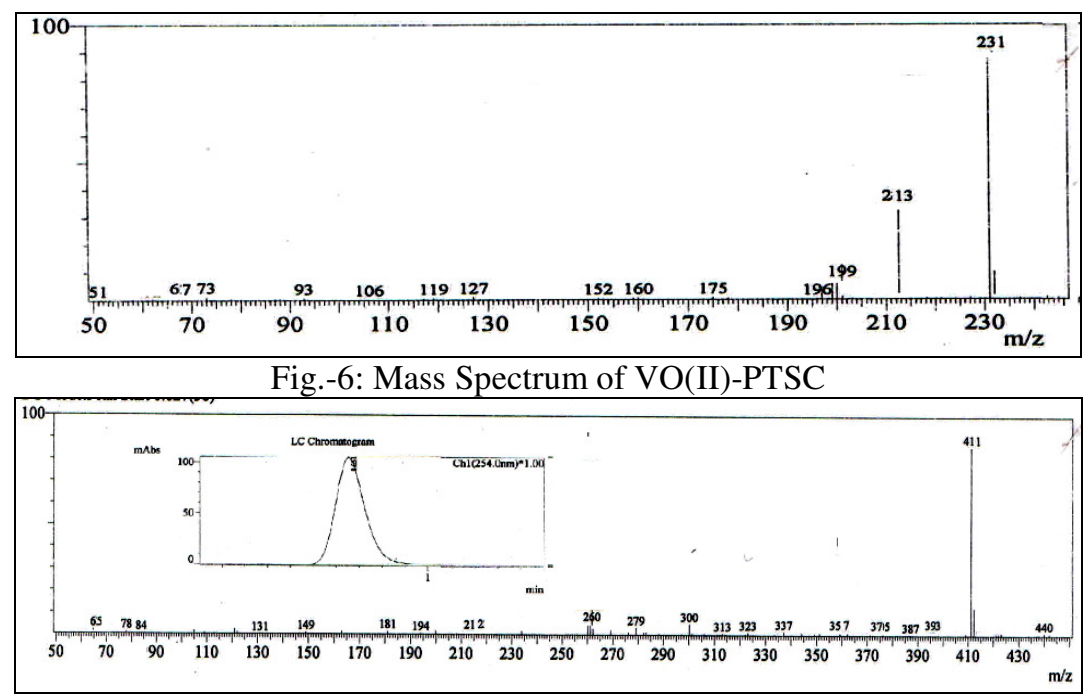

Fig.-7: Mass Spectrum of Zn(II)-PTSC

Thermogravimetric Analysis

TG curve of VO(II)-PTSC (Fig.-8) indicated the decomposition of the complex in four steps. Weight loss of $7.67 \%$ up to $276^{\circ} \mathrm{C}$ was in two steps indicating the loss of one mole of coordinated water. From $276^{\circ} \mathrm{C}-1085^{\circ} \mathrm{C}$, the weight loss of $20 \%$, in various steps may be due to the decomposition of the complex. Percentage of residue left over at $1085^{\circ} \mathrm{C}$ was $70.92 \%$ indicating partial decomposition of the chelate, and hence it is thermally stable.

TGA of Zn(II)-PTSC chelate (Fig.-9) showed the decomposition of the complex in five steps. Weight loss of $4.5 \%$ up to $150^{\circ} \mathrm{C}$ indicated the loss of one mole of lattice water. Weight loss of $10 \%$ between $250^{\circ} \mathrm{C}-280^{\circ} \mathrm{C}$ indicates the evaporation of two moles of coordinated water molecules. At $290^{\circ} \mathrm{C}-396^{\circ} \mathrm{C}$ weight loss of $14.43 \%$, between $394^{\circ} \mathrm{C}-501^{\circ} \mathrm{C}$ the weight loss of $10.26 \%$ and at the $501^{\circ} \mathrm{C}-1100^{\circ} \mathrm{C}$ loss of $20 \%$ of weight indicates the thermal decomposition of the compound. At $1100^{\circ} \mathrm{C}, 37.68 \%$ residue was left indicating partial decomposition of the complex.

IR

In the IR spectrum of PTSC asymmetric and symmetric stretching frequencies of $v_{\mathrm{NH} 2}$ have been observed at $3407 \mathrm{~cm}^{-1}$ and $3284 \mathrm{~cm}^{-1}$ respectively. One of $v_{\mathrm{NH}}$ peak $\left(3407 \mathrm{~cm}^{-1}\right)$ of $v_{\mathrm{NH} 2}$ moiety was absent in the IR spectrum of VO(II)-PTSC (Fig.-10) and the peak $\left(3284 \mathrm{~cm}^{-1}\right)$ has been shifted to $3360 \mathrm{~cm}^{-1}$ in the complex. This may be because of thione-thiol tautomerism. The $v_{\mathrm{C}=\mathrm{S}}$ peak observed at $1269 \mathrm{~cm}^{-1}$ in the IR spectrum of PTSC is absent in the complex and an extra peak observed at $731 \mathrm{~cm}^{-1}\left(v_{\mathrm{C}-\mathrm{S}}\right)$ indicating participation ' $\mathrm{S}$ ' with the dissociation of '-SH' proton in thiol form (thione-thiol tautomerism). The $v_{\mathrm{NH}}$ (N1) peak $\left(3193 \mathrm{~cm}^{-1}\right)$ in the IR spectrum of PTSC has been shifted to lower frequency region $\left(3184 \mathrm{~cm}^{-1}\right)$ in the VO(II)-PTSC due to the back donation of electrons from metal ion indicating binding of ' $N$ '(1) to metal ion. In the IR spectrum of PTSC $v_{\mathrm{NH}(\mathrm{N} 2)}$ peak observed at $3140 \mathrm{~cm}^{-1}$ was absent in the complex and an extra peak corresponds to $v_{\mathrm{C}-\mathrm{N}}$ at $1400 \mathrm{~cm}^{-1}$ has been observed indicating the participation of ' $\mathrm{N}$ ' (2) adjacent to thioketo group by the dissociation of $\mathrm{NH}$ proton. $v_{\mathrm{C}=\mathrm{O}}$ peak which was noted at $1683 \mathrm{~cm}^{-1}$ in the spectrum of PTSC, has been shifted to lower frequency region $1612 \mathrm{~cm}^{-1}$ indicating binding of 
oxygen to the metal ion in the keto form. The binding of all the sites to a single VO(II) ion may result in strain of complex. Therefore two sites $\left(v_{\mathrm{NH}(\mathrm{N} 1)}\right.$ and ' $\mathrm{S}$ ' via CS sites) coordinate with one metal ion other two sites ('O' of $\mathrm{CO}$ and $v_{\mathrm{NH}}(\mathrm{N} 2)$ sites) coordinate with another metal ion resulting in a polynuclear complex which has been supported by its thermal stability. The peak at $952 \mathrm{~cm}^{-1}$ may be due to $\mathrm{V}=\mathrm{O}$ stretching ${ }^{34}$.

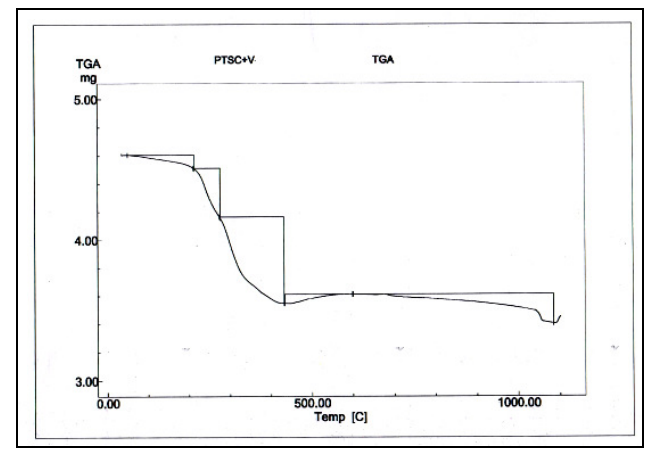

Fig.-8:TGA Graph of VO(II)-PTSC

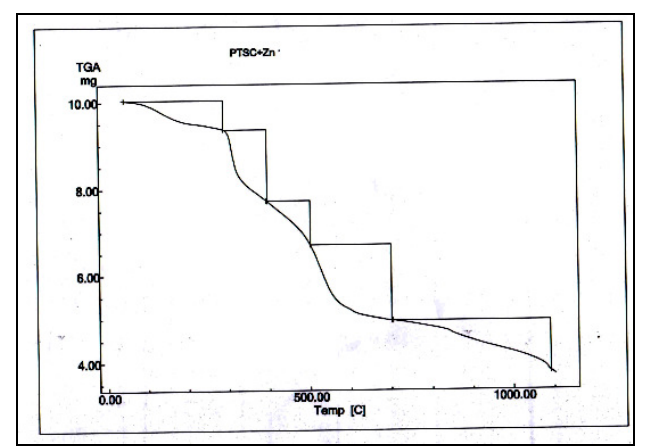

Fig.-9:TGA Graph of Zn(II)-PTSC

In the IR spectrum Zn(II)-PTSC complex, the $v_{\mathrm{NH}(\mathrm{N} 1)}$ peak observed in the Infra red spectrum of PTSC at $3193 \mathrm{~cm}^{-1}$ was shifted to higher frequency region $3292 \mathrm{~cm}^{-1}$ (Fig.-11) indicating the participation of ' $N$ '(1) in the bonding without deprotonation. The $v_{\mathrm{NH}(\mathrm{N} 2)}$ peak which was observed in the IR spectrum of PTSC at $3140 \mathrm{~cm}^{-1}$ has been shifted to a higher frequency region at $3184 \mathrm{~cm}^{-1}$ in the complex. The $v_{\mathrm{C}=\mathrm{S}}$ peak observed at $1269 \mathrm{~cm}^{-1}$ in the IR spectrum of PTSC was absent in the complex and an extra peak observed at $746 \mathrm{~cm}^{-1}\left(v_{\mathrm{C}-\mathrm{S}}\right)$ indicating participation of ' $\mathrm{S}$ ' with the dissociation of '-SH' proton in thiol form (thione-thiol tautomerism ${ }_{\mathrm{S}}^{\mathrm{HC}}=\mathrm{NH}$ ). Due to participation of ' $\mathrm{S}$ ' in the bonding, the $v_{\mathrm{NH}}$ of ' $\mathrm{N}$ '(4) asymmetric stretching frequency increased to $3464 \mathrm{~cm}^{-1}$ and other symmetric peak was absent $\left(3284 \mathrm{~cm}^{-1}\right)$ in the complex. Therefore ' $N$ '(1) and ' $S$ ' acts as binding sites and form a five-membered chelate with $\mathrm{Zn}$ (II) ion.

From Far-IR spectra of the complexes, there is clear evidence of the presence of $v_{\mathrm{M}-\mathrm{O}}\left(400-430 \mathrm{~cm}^{-1}\right), v_{\mathrm{M}-\mathrm{S}}$ $\left(355-395 \mathrm{~cm}^{-1}\right) v_{\mathrm{M}-\mathrm{N}}\left(435-485 \mathrm{~cm}^{-1}\right)$ and $v_{\mathrm{M}-\mathrm{OH} 2}\left(400-440 \mathrm{~cm}^{-1}\right)$ peaks ${ }^{35}$.

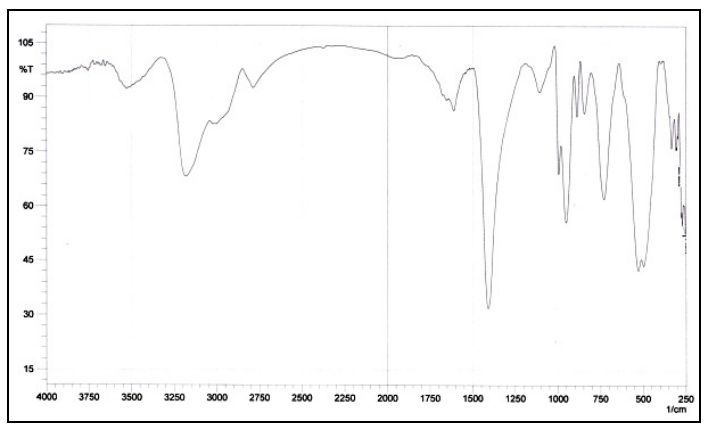

Fig.-10: IR Spectrum of VO(II)-PTSC

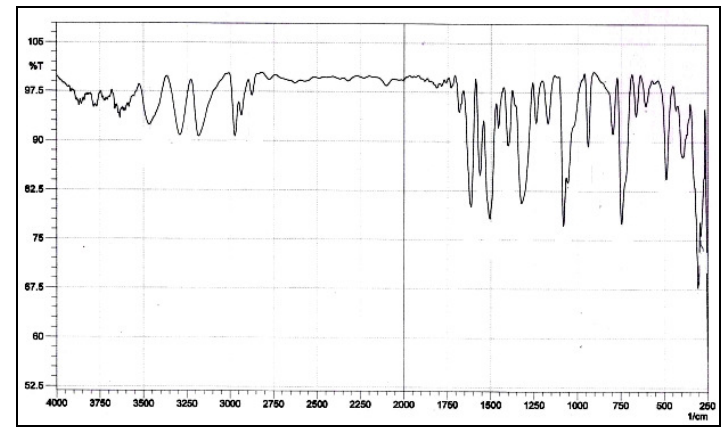

Fig.-11: IR Spectrum of Zn(II)-PTSC

\section{UV-Visible}

UV-Visible spectrum of VO(II)-PTSC complex (Fig.-12) showed characteristic bands at $16,666 \mathrm{~cm}^{-1}$ $\left({ }^{2} \mathrm{~B}_{2} \mathrm{~g} \rightarrow{ }^{2} \mathrm{~B}_{1} \mathrm{~g}\right), 18,340 \mathrm{~cm}^{-1}\left({ }^{2} \mathrm{~B}_{2} \mathrm{~g} \rightarrow{ }^{2} \mathrm{~A}_{1} \mathrm{~g}\right)$ and $37,453 \mathrm{~cm}^{-1}$ (charge transfer transition). Due to nonsymmetrical arrangements of $\mathrm{V}=\mathrm{O}$ bond along the axis, complex show distortion from its octahedral geometry.

\section{ESR and Magnetic Susceptibility}

ESR spectrum of VO(II)-PTSC (Fig.-13) showed the $g$ values $g_{x}=2.0082, g_{y}=1.9795$ and $g_{z}=1.9516$ indicating anisotropy and the distorted octahedral geometry with an unpaired electron. The calculated magnetic moment of $\mathrm{VO}$ (II)-PTSC is $1.12 \mathrm{BM}$ and provides evidence for the presence of one unpaired electron and this abnormal value also reveals the poly nucleic nature of the chelate. 
RASĀYAN J. Chem.

Vol. 12 | No. 3 |1530 - 1539| July - September | 2019

Based on the analysis of the spectral and analytical techniques employed and equilibrium studies the following tentative structures (Fig.-14) have been proposed for the metal complexes.

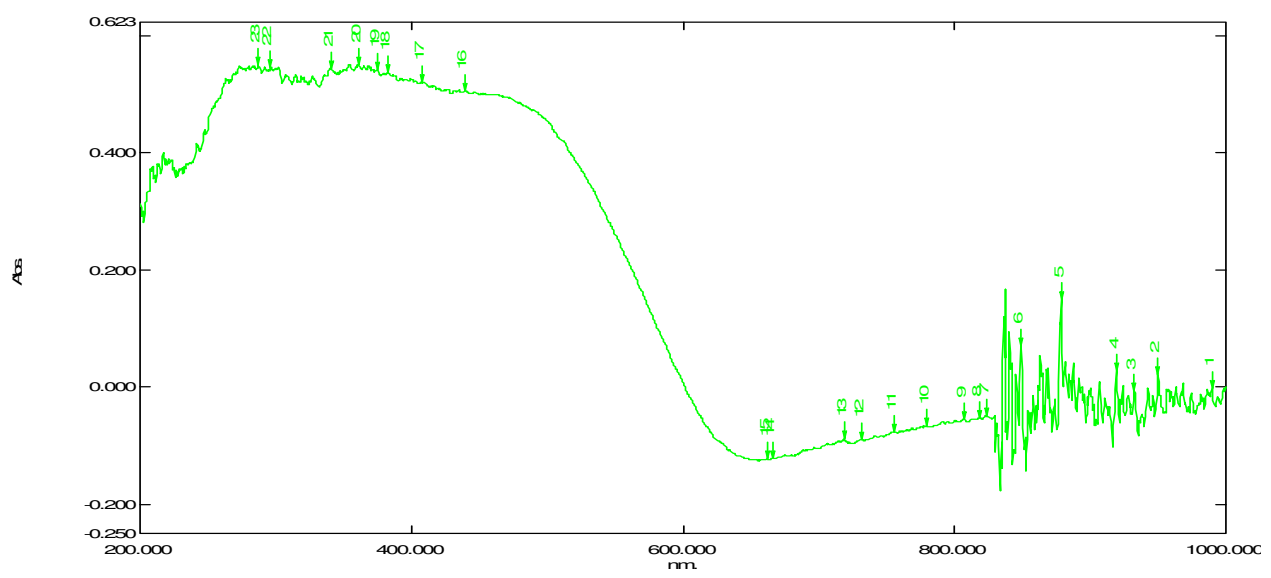

Fig.-12: UV-Visible Spectrum of VO(II)-PTSC

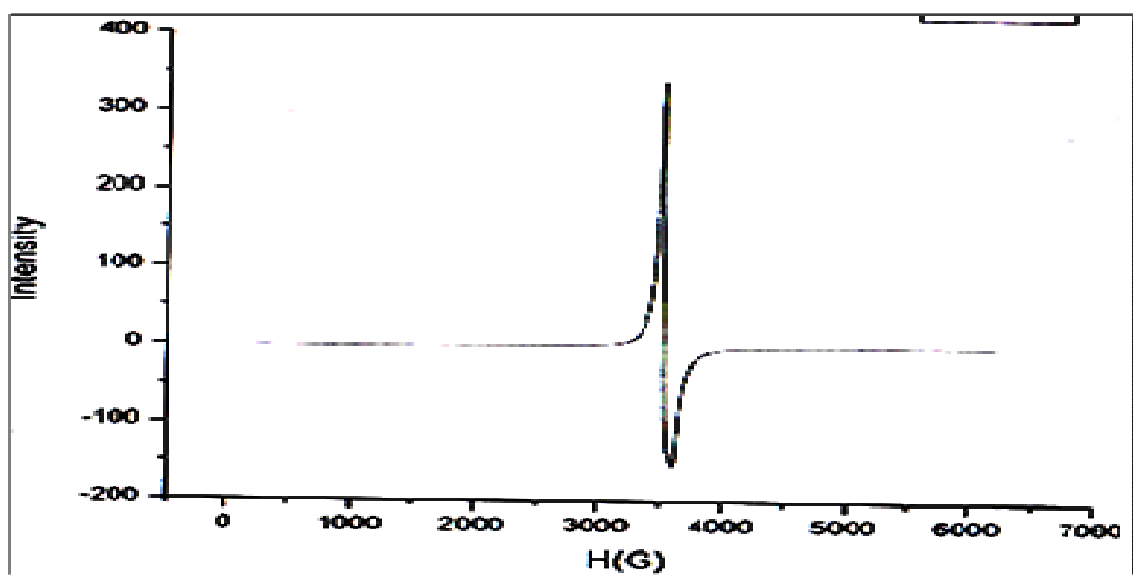

Fig.-13: ESR Spectrum of VO(II)-PTSC
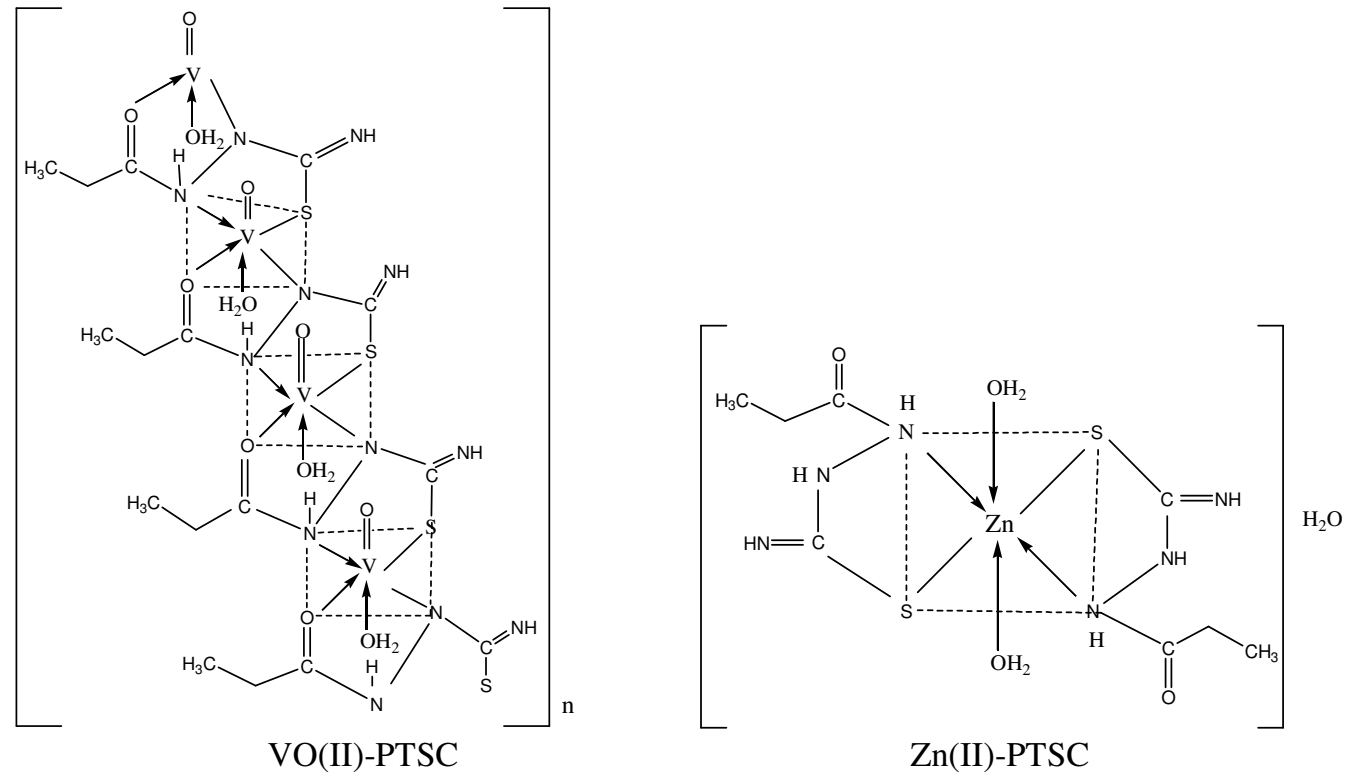

Fig.-14: Tentative Structures of VO(II)-PTSC and Zn(II)-PTSC 


\section{DNA Cleavage Studies}

In the complexes, the metal ions serve as Lewis acids and activate the phospho-diester links for nucleophilic attack. The metal coordinated water species acts as a nucleophile. When DNA is subjected to electrophoresis, the intact SC form migrates faster. When scission occurs due to the action of chelate, Super coiled (SC) form will relax to nicked (NC) form that migrates slowly. Cleavage of both the types of strands leads to linear form, which migrates between SC and NC forms. The reason being shorter molecules migrate more easily through the fine pores of the gel. It has been observed (Fig 15) that both the complexes of PTSC promoted hydrolytic cleavage of plasmid pBR322 to a certain extent due to scission in super coiled forms of DNA to Nicked forms ${ }^{36-38}$.

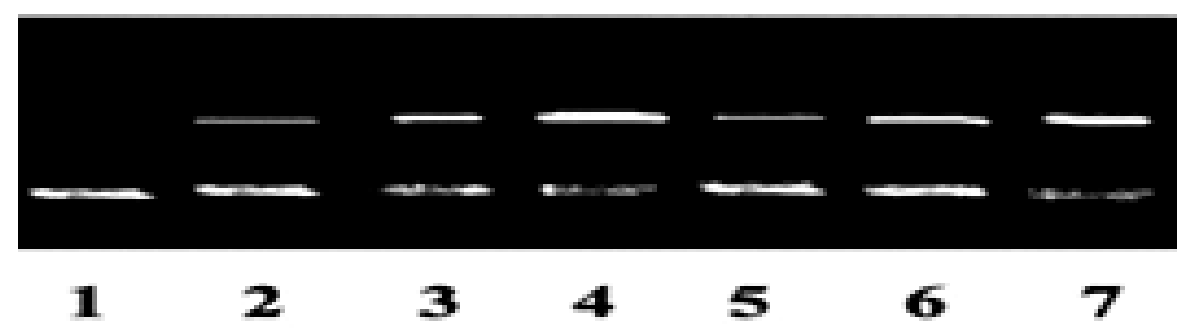

Fig.-15: Pattern of Agarose gel Electrophoresis for the Cleavage of Supercoiled pBR322 DNA by complexes. Lane 1, DNA control, Lane 2-4 DNA+VO(II) (20, 40, $60 \mu \mathrm{M}$ resp.), Lane 5-7 DNA+ Zn(II) (20, 40, $60 \mu \mathrm{M}$ resp.) of

\section{Antibacterial Studies} PTSC.

The PTSC and Zn(II)-PTSC have inhibited the growth of gram-positive and gram-negative bacteria as shown in Table.3. VO(II)-PTSC showed more activity on gram-positive bacteria compared to PTSC. This can be associated with the chelating capacity of the ligand, by partially sharing the positive charge of the metal atom. This leads to delocalization of $\pi$ electron cloud over the chelating ring, resulting in the increase of lipophilic character of the metal ion which favors its permeability into the cell membranes inhibiting the growth of the bacteria ${ }^{39-41}$.

Table-3: Table showing Antibacterial Studies Results in $\mathrm{mm}$

\begin{tabular}{c|c|c|c|c}
\hline Compound & S. aureus & B. subtilis & E. coli & K. pneumoniae \\
\hline PTSC & 6 & - & 6 & 6 \\
\hline VO(II)-PTSC & 10 & 10 & 6 & 6 \\
\hline Zn(II)-PTSC & 6 & 6 & 6 & - \\
\hline
\end{tabular}

\section{CONCLUSION}

Spectral and analytical studies indicate that PTSC forms distorted octahedral complexes in ML composition with $\mathrm{VO}$ (II) and $\mathrm{ML}_{2}$ composition with $\mathrm{Zn}$ (II) ions. Equilibrium studies reveal that PTSC acts as monobasic ligand and forms stable 1:1 and 1:2 (M-L) complex with $\mathrm{Zn}$ (II) ions in DMF media. DNA cleavage studies reveal that both the complexes can cleave SC form of plasmid DNA. Both the solid complexes revealed good activity against gram-positive and gram-negative bacteria.

\section{ACKNOWLEDGMENT}

The authors thank UGC-SERO (6444) for funding, to carry out this study.

\section{REFERENCES}

1. U. Salgın-Go ks, en, N. Go khan-Kelekci, O. Go ktas, Y. Koysal, E. Kilic, S. Isik, G. Aktay, M. Ozalp, Bioorg. Med. Chem., 15, 5738(2007), DOI: 10.1016/j.bmc.2007.06.006

2. M. Sheikhy, A.R. Jalilian, A. Novinrooz, F. Motamedi-Sedeh, J. Biomed. Sci. Eng., 5, 39(2012), DOI: $10.4236 /$ jbise.2012.52006

3. P. Umadevi, K. Deepti, I. Srinath, G. Vijayalakshmi, M. Tarakamji, Int. J. Pharm. Pharm. Sci., 4(3), 379(2012). 
RASĀYAN J. Chem.

Vol. 12 | No. 3 |1530 - 1539| July - September | 2019

4. S.R. Patel, R. Gangwal, A.T. Sangamwar, R Jain, Eur. J. Med. Chem., 6(85), 255(2014), DOI: 10.1016/j.ejmech.2014.07.100

5. O.U. Tan, K. Ozadali, P. Yogeeswari, D. Sriram, A. Balkan, Med. Chem. Res., 21, 2388(2012), DOI: $10.1007 / \mathrm{s} 00044-011-9770-6$

6. V. Alagarsamy, B.A. Kumar, P. Parthiban, R.V. Sheorey, V.R. Solomon, Med. Chem., 10(2), 105(2010).

7. R.A. Rane, S.S.Naphade, P.K. Bangalore, M.B. Palkar, M.S. Shaikh, R. Karpoormath, Bioorg. Med. Chem. Lett., 24, 3079(2014), DOI: 10.1016/j.bmcl.2014.05.018

8. S. Arora, S. Agarwal, S. Singhal, Int. J. Pharm. Pharm. Sci., 6, 34(2014).

9. M.E Mohsen, A.M, Omar, A.A.B. Farghaly, N.H. Hazzai, F.M. Eshba, T.T. Sharabi, J. Pharm. Sci., 70(9),1075(1981), DOI: 10.1002/jps.2600700928

10. I. Perkovic', I. Butula, M. Kralj, I. Martin-Kleiner, J. Balzarini, D. Hadjipavlou-Litina, A.M. Katsori, B. Zorc, Eur. J. Med. Chem., 51, 227(2012), DOI: 10.1016/j.ejmech.2012.02.046

11. A.R. Bhata, F. Athar, R.L.Van Zyl, C.T. Chen, A. Azam, Chem. Biodivers., 5, 764-776(2008), DOI: 10.1002/cbdv.200890073

12. A. Malki, R.Y. Elbayaa, H.M.A. Ashour, C.A. Loffredo, A.M. Yousse, J. Enzyme Inhib. Med. Chem., 3, 1(2014).

13. H.J. Zhang, Y. Qian, D.D. Zhu, X.G. Yang, H.L. Zhu, Eur. J. Med. Chem., 46, 4702(2011), DOI: 10.1016/j.ejmech.2011.07.016

14. A.T. Mavrova, D. Wesselinova, J.A. Tsenov, L.A. Lubenov, Eur. J. Med. Chem., 86, 676(2014), DOI: $10.1016 /$ j.ejmech.2014.09.032

15. F. Cognasse, H. Hamzeh-Cognasse, A. Chabert, E. Jackson, C.A. Arthaud, O. Garraud, A. McNicol, BMC Immunol., 15, 1(2014), DOI: 10.1186/1471-2172-15-15

16. S.W. Kerrigan, I. Douglas, A. Wray, J. Heath, M.F. Byrne, D. Fitzgerald, D. Cox, Blood, 100, 509(2002), DOI: 10.1182/blood.V100.2.509

17. J.H. Meurman, J. Oral Microbiol, 2, 1(2010), DOI: 10.3402/jom.v2i0.5195

18. P. Monika, W. Maciej, M.K. Malgorzata, K. Katarzyna, M. Barbara, P.S. Anna, G. Agata, G. Grazyna, Med. Chem. Res., 25(8), 1666(2016), DOI: 10.1007/s00044-016-1599-6

19. C.X. Zhang and S. Lippard, J. Curr. Opin. Chem, Biol., 5, 481(2003).

20. C.J. Burrows and J.G. Muller, Che. Rev., 98, 1109(1998), DOI: $10.1021 / \mathrm{cr} 960421 \mathrm{~s}$

21. S. Murali, C.V. Sastri. and B.G. Maiya, Proc. Indian Acad. Sci. (Chem. Sci.) 114, 403(2002).

22. H. Beyer, K. Carl Friedrich, B. Gertraut, J. L Annalen, der Chemie, 637, 135(1960).

23. H.M. Irving and H.S. Rossetti; J. Chem. Soc., 3397(1953), DOI: 10.1039/JR9530003397

24. H.M. Irving, and H.S. Rossetti, J. Chem. Soc., 2904(1954), DOI: 10.1039/JR9540002904

25. H.M. Irving, and H.S. Rossotti, Acta. Chem. Scand., 10, 72(1956), DOI: 10.3891/acta.chem.scand.10-0072

26. K. Laxmi, G. Bhargavi, B. Sireesha and Ch. Sarala Devi; Bull. Chem. Soc. Ethiop., 20(1), 161(2006), DOI: $10.4314 /$ bcse.v20i1.21156

27. G. Bhargavi, B. Sireesha and Ch. Sarala Devi; Bulletin of Pure and Applied Sciences, 21C, (No.1), 1(2002).

28. G. Bhargavi, B. Sireesha and Ch. Sarala Devi; J. Indian Chem. Soc., 79, 826(2002).

29. Aliya, B. Sireesha, Ch. Venkataramana Reddy and Ch. Sarala Devi; J. Indian Chem. Soc., 85, 926(2008).

30. Firasath Unnisa, B. Sireesha, and P.A. Nagarjuna, Journal of Chemistry and Chemical Sciences, 6(8), 747(2016).

31. A. Sabalini, A. Vacca and P. Gins; Talanta, 21, 53(1974).

32. K. Nakamoto, "Infrared spectra of Inorganic and Coordination Compounds" $2^{\text {nd }}$ ed. Wiley Interscience, 223: 236(1970).

33. A.I. Vogel, "A Text Book of Quantitative Inorganic Analysis" $33^{\text {rd }}$ Ed. Londman, London, 264(1968). 
RASĀYAN J. Chem.

Vol. 12 | No. 3 |1530 - 1539| July - September | 2019

34. P.I.S. Maia and F.R. Pavan, C.Q.F. Leite, S.S. Lemos, G.F DE Sousa, A.A. Batista, O.R. Nascimento, J. Ellena, E.E. Castellano, E. Niquet, V M Deflon. Polyhedron, 28, 398(2009), DOI: 10.1016/j.poly.2008.11.017

35. Graham Patrick, An Introduction to Medicinal Chemistry, 5th edition, Oxford University Press, (2013).

36. P.R. Reddy and A. Shilpa, Indian Journal of Chemistry, 49A, 1003(2010).

37. R. Kavitha, Ch. V.R. Reddy and B. Sireesha, J. Indian Chem. Soc., 95, 495(2018).

38. M. Vijayalakshmi., RASAYAN J. Chem., 11(2), 857(2018), DOI: 10.31788/RJC.2018.1123033

39. M.M. El-ajaily, A.A. Maihub, U.K. Mahanta, G. Badhei, R.K. Mohapatra, P.K. Das, RASAYAN J. Chem.,11(1), 166(2018), DOI:10.7324/RJC.2018.1111988

40. P. Senthilkumar, V. Srinivas, M.N. Sivakumar., RASAYAN J. Chem.,11(1), 175(2018). DOI:10.7324/RJC.2018.1111864

41. S.P. Mydhili, B. Sireesha, Ch.V.R. Reddy, and P.A. Nagarjuna, Der Pharma Chemica, 8(16), 138(2016).

[RJC-5182/2019] 